\title{
Szacowanie ilości materii organicznej na podstawie zawartości pierwiastków śladowych
}

\section{Total organic carbon (TOC) quantification based on trace elements}

\author{
Anna Przelaskowska, Urszula Zagórska, Maja Mroczkowska-Szerszeń, Konrad Ziemianin \\ Instytut Nafty i Gazu - Państwowy Instytut Badawczy
}

\begin{abstract}
STRESZCZENIE: Wiele pierwiastków śladowych wykazuje związki z materią organiczną TOC. Zależności te pozwalają na wykorzystanie pomiarów składu chemicznego do modelowania zawartości TOC. Celem przedstawionej pracy była ocena możliwości szacowania ilości materii organicznej na podstawie zawartości pierwiastków śladowych takich jak: Ni, Cu, Mo, U, V, Zn, Cr, Sr, Pb i Co dla głębokomorskich łupków sylurskich. Przebadano związki korelacyjne pomiędzy poszczególnymi pierwiastkami i zawartością materii organicznej. Następnie utworzono modele pozwalające na wyliczenie ilości materii organicznej na podstawie zawartości pierwiastków, dla których zaobserwowano znaczące związki z TOC. Wykorzystano zarówno bardziej dokładne badania składu chemicznego wykonane metodą spektrometrii masowej ICP-MS, jak i pomiary o niższej wykrywalności wykonane przenośnym spektrometrem fluorescencji rentgenowskiej EDXRF. Stwierdzono zależności pomiędzy zawartością pierwiastków śladowych a ilością materii organicznej TOC dla pierwiastków takich jak: $\mathrm{V}, \mathrm{Cu}, \mathrm{U}, \mathrm{Ni}, \mathrm{Mo}, \mathrm{Cr}$ (metoda ICP-MS) oraz V, Cu, Cr i Ni (metoda XRF). Za pomocą metody regresji wielorakiej skonstruowano modele o współczynnikach determinacji $R^{2}$ od 0,84 do 0,92 (dla metody ICP-MS) i od 0,75 do 0,78 (dla metody XRF) umożliwiające szacowanie ilości materii organicznej na podstawie zawartości pierwiastków śladowych. Uzyskane modele matematyczne pozwalają na wyliczanie zawartości materii organicznej TOC dla głębokomorskich, bogatych w materię organiczną łupków sylurskich na bazie pomiarów pierwiastków śladowych wykonanych metodą spektrometrii masowej ICP-MS oraz metodą fluorescencji rentgenowskiej XRF. Szczególnie istotna jest możliwość wykorzystania pomiarów przeprowadzonych przenośnym spektrometrem fluorescencji rentgenowskiej. Badania te są szybkie, mogą być prowadzone na próbkach okruchowych w trakcie trwania wiercenia. Modele oparte na wynikach XRF pozwalają więc w szybki sposób modelować zawartość TOC jeszcze w trakcie wiercenia.
\end{abstract}

Słowa kluczowe: zawartość materii organicznej (TOC), pierwiastki śladowe, regresja wieloraka, modele matematyczne.

ABSTRACT: Many trace elements are associated with organic matter. The total organic carbon (TOC) content can be thus calculated basing on the chemical composition measurements. The aim of the presented paper was to evaluate the possibility of estimating the organic matter amount on the basis of trace elements such as: $\mathrm{Ni}, \mathrm{Cu}, \mathrm{Mo}, \mathrm{U}, \mathrm{V}, \mathrm{Zn}, \mathrm{Cr}, \mathrm{Sr}, \mathrm{Pb}$ and $\mathrm{Co}$, for Silurian black shales. Correlations between individual elements and total organic carbon were analysed. Next, mathematical models allowing to calculate the amount of organic matter based on the content of elements significantly related to TOC were constructed. Both more accurate chemical composition analyses (ICP-MS mass spectrometry method) and measurements of lower detectability performed with portable X-ray fluorescence spectrometer EDXRF were used. The relationships between the content of trace elements and the total organic carbon content TOC were found for such elements as: V, Cu, U, Ni, Mo, Cr (ICP-MS) and V, Cu, Cr and Ni (XRF). Mathematical models allowing for TOC quantification based on trace elements, characterized by determination coefficients $\mathrm{R}^{2}$ from 0.84 to 0.92 (for ICP MS method) and from 0.75 to 0.78 (for XRF method) were obtained with the use of the multiple regression method. The mathematical models allow to calculate the content of organic matter TOC for Silurian black shales on the basis of trace element data obtained by both mass spectrometry ICP-MS and X-ray fluorescence spectrometry EDXRF. The possibility of using measurements made with a portable X-ray fluorescence spectrometer is particularly important. Such measurements are fast and can be carried out on cuttings during the drilling process. Models based on XRF results therefore allow for quick modelling of the TOC content during the drilling process.

Key words: total organic carbon (TOC) content, trace elements, multiple regression, mathematical models.

Autor do korespondencji: A. Przelaskowska, e-mail: anna.przelaskowska@inig.pl

Artykuł nadesłano do Redakcji: 08.12.2020 r. Zatwierdzono do druku: 02.04.2021 r. 


\section{Wstęp}

Wiele pierwiastków śladowych wykazuje związki z materią organiczną TOC. Zależności te pozwalają na wykorzystanie pomiarów składu chemicznego do modelowania zawartości TOC. W literaturze opisywane są metody wyliczania składu mineralnego (Marsala et al., 2011; Alnahwi i Loucks, 2019) oraz zawartości TOC (Alnahwi i Loucks, 2019) na podstawie badań składu chemicznego wykonanych przenośnym spektrometrem fluorescencji rentgenowskiej. Alnahwi i Loucks (2019) zastosowali pomiary składu pierwiastkowego do wygenerowania ciągłych zawartości TOC w profilu otworu. Dobre korelacje TOC z pierwiastkami takimi jak $\mathrm{Mo}, \mathrm{Cu}$ i Ni (współczynniki korelacji liniowej odpowiednio $0,75 ; 0,61$ i 0,71$)$ pozwoliły na wykorzystanie tych zależności do wygenerowania wartości TOC przy użyciu sieci neuronowych. Liu et al. (2013) i Saez et al. (2009) szacowali zawartość TOC $\mathrm{w}$ osadach jeziornych na podstawie innego parametru uzyskanego z pomiarów XRF - stosunku rozpraszania Rayleigha (promieniowanie pierwotne ulega rozproszeniu bez straty energii) do efektu Comptona, polegającego na wybiciu elektronu z zewnętrznej powłoki atomu kosztem części energii padającego fotonu.

Celem przedstawionej pracy była ocena możliwości szacowania ilości materii organicznej na podstawie zawartości pierwiastków śladowych takich jak: Ni, Cu, Mo, U, V, Zn, Cr, Sr, $\mathrm{Pb}$ i Co dla głębokomorskich łupków sylurskich. Przebadano związki korelacyjne pomiędzy poszczególnymi pierwiastkami i zawartością materii organicznej. Następnie utworzono modele matematyczne pozwalające na wyliczenie ilości materii organicznej TOC na podstawie zawartości pierwiastków, dla których zaobserwowano wyraźne związki z TOC.

\section{Podstawy teoretyczne}

Wiele pierwiastków śladowych występuje w wodzie morskiej w postaci rozpuszczalnej lub zaadsorbowanej na powierzchniach zawieszonych cząstek osadów. Przedostanie się rozpuszczonych pierwiastków śladowych z kolumny wody do osadów następuje na skutek procesów biotycznych lub abiotycznych. Procesy biotyczne polegają na wykorzystywaniu pierwiastków śladowych przez plankton (głównie fitoplankton) jako mikroskładników odżywczych. Procesy abiotyczne są ograniczone w warunkach utleniających, a szczególnie rozpowszechnione w warunkach redukcyjnych. Składają się na nie adsorpcja jonów metali na powierzchniach substratów mineralnych lub organicznych, formowanie się kompleksów organometalicznych oraz wytrącanie się siarczków $(\mathrm{Fe})$ lub/i nierozpuszczalnych tlenowodorotlenków (Tribovillard et al., 2006).
Tabela 1. Podział środowisk sedymentacji na podstawie warunków utleniająco-redukcyjnych (Tyson i Pearson, 1991)

Table 1. Redox classification of the depositional environments (Tyson and Pearson, 1991)

\begin{tabular}{|c|c|c|c|}
\hline & & $\mathrm{O}_{2}\left[\mathrm{mlO}_{2} / \mathrm{lH}_{2} \mathrm{O}\right]$ & \\
\hline Utleniając & (ang. oxic) & $>2$ & \\
\hline $\begin{array}{r}\text { Prze } \\
\text { (ang. subo }\end{array}$ & $\begin{array}{l}\text { ściowe } \\
x i c, \text { dysoxic) }\end{array}$ & $2>\mathrm{O}_{2}>0,2$ & \\
\hline Pedulcruine & $\begin{array}{l}\text { anoksyczne } \\
\text { (ang. anoxic) }\end{array}$ & $<0,2$ & $\begin{array}{l}\text { brak wolnego } \mathrm{H}_{2} \mathrm{~S} \\
\text { w kolumnie wody }\end{array}$ \\
\hline Кесиксулпе & $\begin{array}{l}\text { euksyniczne } \\
\text { (ang. euxinic) }\end{array}$ & 0 & $\begin{array}{l}\text { wolny } \mathrm{H}_{2} \mathrm{~S} \text { obecny } \\
\text { w kolumnie wody }\end{array}$ \\
\hline
\end{tabular}

W konsekwencji wzbogacenie osadów w pierwiastki śladowe zachodzące na skutek zróżnicowanych procesów odzwierciedla warunki panujące w czasie depozycji i wczesnej diagenezy. Koncentracje czy stosunki między zawartościami pierwiastków śladowych są jednym z najczęściej wykorzystywanych wskaźników warunków redox (warunki suboksyczne, anoksyczne i euksyniczne, tabela 1), jak i zawartości substancji organicznej (Pailler et al., 2002; Algeo i Maynard, 2004).

Wyraźne wzbogacenie w pierwiastki śladowe wykazują osady bogate w organikę, szczególnie te osadzane w warunkach euksynicznych, a niewielkie - osady ubogie w organikę. Przyczyną takiego stanu rzeczy jest fakt, że wiele pierwiastków śladowych występuje na kilku stopniach utlenienia i formy zredukowane, obecne w warunkach niewielkiej ilości tlenu, częściej tworzą kompleksy z kwasami organicznymi, roztwory stałe $\mathrm{z}$ autigenicznymi siarczkami lub są wytrącane w postaci nierozpuszczalnych tlenowodorotlenków. Warunki i procesy charakterystyczne dla środowiska o niewielkiej ilości tlenu, takie jak zwiększona dostępność substratów węgla organicznego i obecność wolnego siarkowodoru, mają wpływ na zawartość tych pierwiastków (Morse i Luther, 1999; Algeo i Maynard, 2004). Istotnym czynnikiem wpływającym na wzbogacenie osadów w pierwiastki śladowe jest również cykl redox Mn i Fe (Algeo i Maynard, 2004; Tribovillard et al., 2006). Jony $\mathrm{Mn}^{2+}$ są niestabilne w natlenionej wodzie i są utleniane do postaci nierozpuszczalnych tlenków i wodorotlenków. Poniżej granicy pomiędzy środowiskiem tlenowym i anoksycznym dochodzi do redukcyjnego rozpuszczania tych związków. Mn jest uwalniany i w postaci rozpuszczalnej dyfunduje $\mathrm{w}$ górę do kolumny wody lub w głąb osadu. Pierwiastki śladowe są adsorbowane w związkach Mn, przenoszone do osadu, a potem uwalniane w warunkach redukcyjnych na lub poniżej granicy woda-osad (Tribovillard et al., 2006). Pierwiastki śladowe, których dystrybucja jest związana z cyklem redox $\mathrm{Fe} / \mathrm{Mn}$, to: $\mathrm{Ni}, \mathrm{Cu}, \mathrm{Zn}$, $\mathrm{Co}, \mathrm{Pb}, \mathrm{Mo}, \mathrm{V}$ i Cr (Tribovillard et al., 2006).

Pierwiastki śladowe prezentują różną wrażliwość na warunki redox i zróżnicowane zachowanie w stosunku do materii 
organicznej. Niektóre pierwiastki mogą być bardziej związane ze źródłami detrytycznymi (np. Cr, Co) (Craigie, 2018) lub wykazywać dużą mobilność po depozycji i pogrzebaniu osadu ( $\mathrm{P}, \mathrm{Ba}, \mathrm{Zn}, \mathrm{Pb}$, Cd). Przedstawiony poniżej schemat (rys. 1) oparty jest na analizie zachowania pierwiastków takich jak: U, V, Mo, Ni i Cu. Pierwiastki te są najmniej podatne na wpływy czynników innych niż warunki redox i zawartość TOC (Algeo i Maynard, 2004; Tribovillard et al., 2006).

W warunkach utleniających i suboksycznych (generalnie TOC $<2 \%$ wag.) pierwiastki śladowe są deponowane przede wszystkim w połączeniu $\mathrm{z}$ frakcją detrytyczną, co skutkuje brakiem korelacji z TOC. W warunkach anoksycznych (brak wolnego siarkowodoru) pierwiastki śladowe koncentrują się głównie w postaci organometalicznych kompleksów. Występują tutaj wyraźne korelacje między pierwiastkami śladowymi a TOC, ponieważ pobór (absorbcja) pierwiastków śladowych jest ograniczony przez dostępność odpowiednich substratów organicznych (Algeo i Maynard, 2004). W warunkach euksynicznych, gdy występuje wolny siarkowodór i pierwiastki śladowe są zredukowane do swoich najniższych stopni utlenienia, nierozpuszczalne siarczki i tlenowodorotlenki mogą wytrącać się bezpośrednio na granicy sedyment - osad. Skutkiem jest wyraźne wzbogacenie w U i V i słaba korelacja tych pierwiastków z TOC, ponieważ występują one głównie w fazach mineralnych. $\mathrm{Ni} \mathrm{i} \mathrm{Cu}$ są związane z substancją organiczną i wykazują silną korelację z TOC. W warunkach tych widoczne jest również wzbogacenie w Mo, ponieważ pierwiastek ten łączy się z pirytem i materią organiczną bogatą w siarkę (Morse i Luther, 1999; Algeo i Maynard, 2004; Tribovillard et al., 2006).

Należy przy tym zaznaczyć, że przedstawiony schemat może być prawidłowy tylko w systemach otwartego morza, gdzie zapewniona jest ciągła dostawa pierwiastków śladowych rozpuszczonych w wodzie morskiej. W zamkniętych basenach, gdzie tempo przechwytywania pierwiastków śladowych w osadzie przewyższa tempo dostawy związanej z krążeniem wody, mogą występować inne relacje pomiędzy TOC i pierwiastkami śladowymi.

\section{Analiza związków pomiędzy zawartością pierwiastków śladowych a ilością materii organicznej TOC}

Wykonano analizę związków pomiędzy zawartością pierwiastków śladowych takich jak: Ni, Cu, Mo, U, V, Zn, Cr, Sr, $\mathrm{Pb}$ i Co a zawartością substancji organicznej TOC dla osadów głębokomorskich (gazonośnych łupków sylurskich) przebadanych w ramach programu Polskie Technologie dla Gazu
Łupkowego Blue Gas pt. Metodologia wyznaczania sweet spotów na podstawie własności geochemicznych, petrofizycznych, geomechanicznych w oparciu o korelację wyników badań laboratoryjnych z pomiarami geofizycznymi i model generacyjny $3 D$ (Matyasik et al., 2016, 2020; Matyasik, 2017). Badania składu chemicznego wykonane zostały metodą spektrometrii masowej ICP-MS oraz metodą fluorescencji rentgenowskiej EDXRF za pomocą przenośnego spektrometru S1 Titan firmy Bruker. Badania metodą fluorescencji rentgenowskiej prowadzone są od wielu lat w Zakładzie Geofizyki Wiertniczej INiG - PIB (Skupio, 2014; Skupio et al. 2020) i wykorzystywane do weryfikacji analiz składu mineralnego oraz na potrzeby analizy chemostratygraficznej. Zawartość substancji organicznej TOC określona została metodą pirolizy Rock-Eval za pomocą aparatu Rock-Eval 6 Turbo (Vinci Technologies).

Przebadano związki pomiędzy zawartością pierwiastków śladowych a ilością materii organicznej TOC. Opierając się na przeprowadzonej analizie, utworzono modele pozwalające na wyliczenie ilości materii organicznej TOC na podstawie zawartości wybranych pierwiastków śladowych. Modele utworzono przy zastosowaniu regresji wielorakiej (program STATISTICA), do analizy wykorzystano te pierwiastki, dla których zaobserwowano związek korelacyjny z TOC.

Stwierdzono wyraźne zależności pomiędzy zawartościami pierwiastków śladowych pomierzonymi metodą ICP-MS i TOC. Najlepsze korelacje otrzymano dla $\mathrm{V}, \mathrm{U}$ i Cu $\left(R^{2}\right.$ powyżej 0,68 ; rys. 2 i 3). Zależności nieco słabsze, ale również świadczące o wyraźnym związku między poszczególnymi pierwiastkami a TOC, uzyskano dla Ni, Cr i Mo (rys. 2 i 3). W przypadku pozostałych analizowanych pierwiastków śladowych, takich jak: $\mathrm{Zn}, \mathrm{Sr}, \mathrm{Pb}$ i Co, nie zaobserwowano żadnych zależności.

Wyraźne korelacje pomiędzy zawartością pierwiastków śladowych pomierzoną metodą fluorescencji rentgenowskiej 

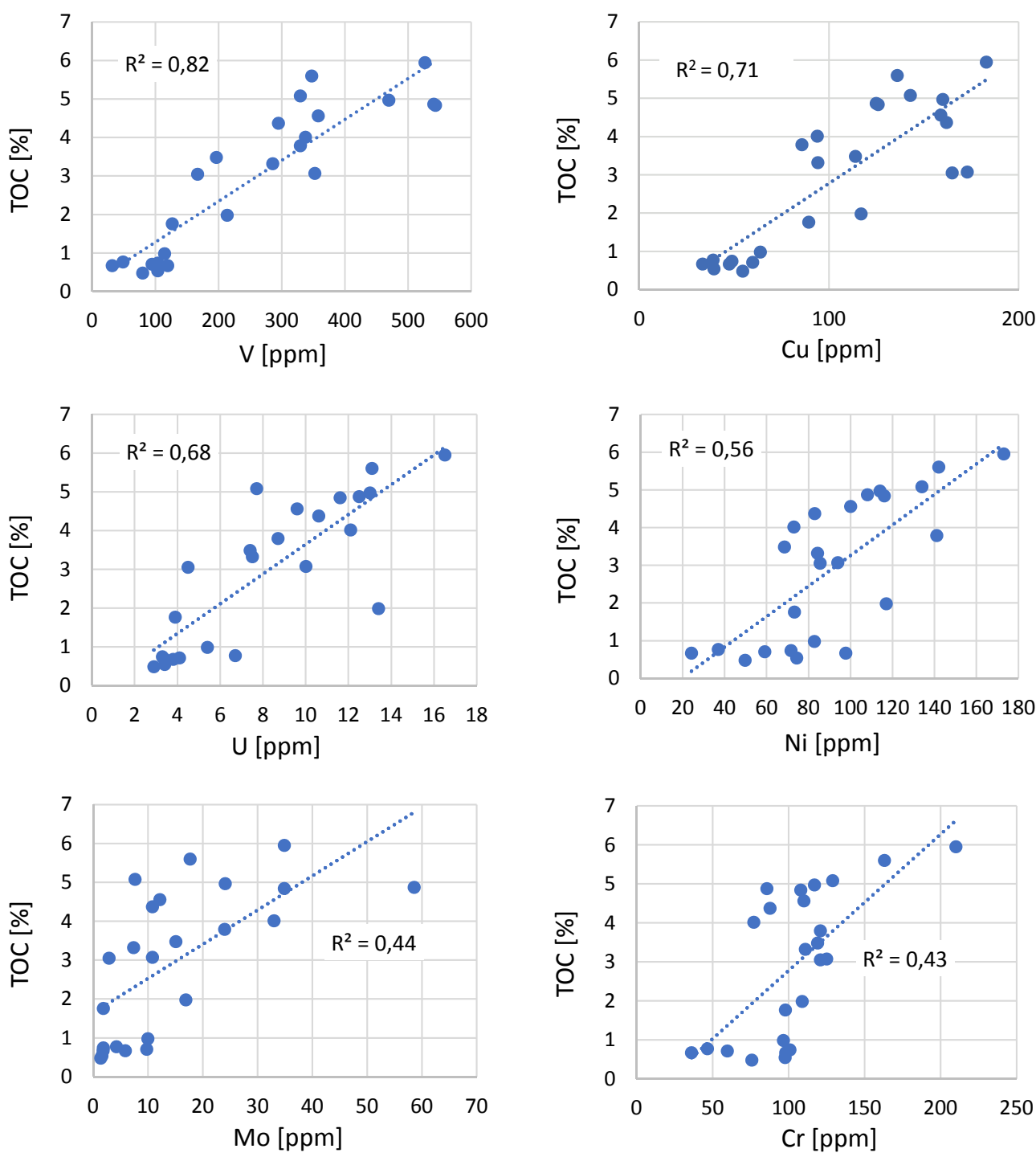

Rys . 2. Korelacje zawartości wybranych pierwiastków śladowych pomierzonych metodą ICP-MS z zawartością materii organicznej TOC w łupkach sylurskich

Fig. 2. Correlations of selected trace elements measured by ICP-MS with total organic content TOC in Silurian shales

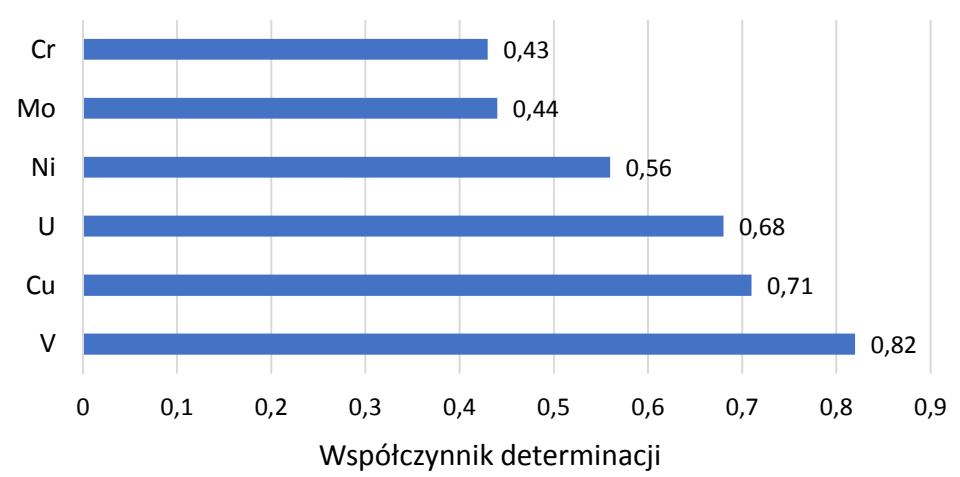

Rys. 3. Współczynniki determinacji pomiędzy wybranymi pierwiastkami śladowymi pomierzonymi metodą ICP-MS a zawartością materii organicznej TOC w łupkach sylurskich Fig. 3. Coefficients of determination between selected trace elements measured by ICP-MS and total organic carbon TOC in Silurian shales

XRF i TOC otrzymano dla dwóch pierwiastków: $\mathrm{V}, \mathrm{Cu}$ (rys. 4 i 5). Dla Ni i Cr również widoczne są tendencje wzrostowe (rys. 4 i 5 ). W przypadku pozostałych przeanalizowanych pierwiastków, takich jak $\mathrm{U}, \mathrm{Mo}, \mathrm{Zn}, \mathrm{Sr}, \mathrm{Pb}$ i Co, nie

zaobserwowano żadnych zależności. Brak zależności pomiędzy Mo i U i TOC i słabsze związki z V, Cu, Cr i Ni niż w przypadku badań ICP-MS wynikają najprawdopodobniej z niższej wykrywalności metody XRF. 

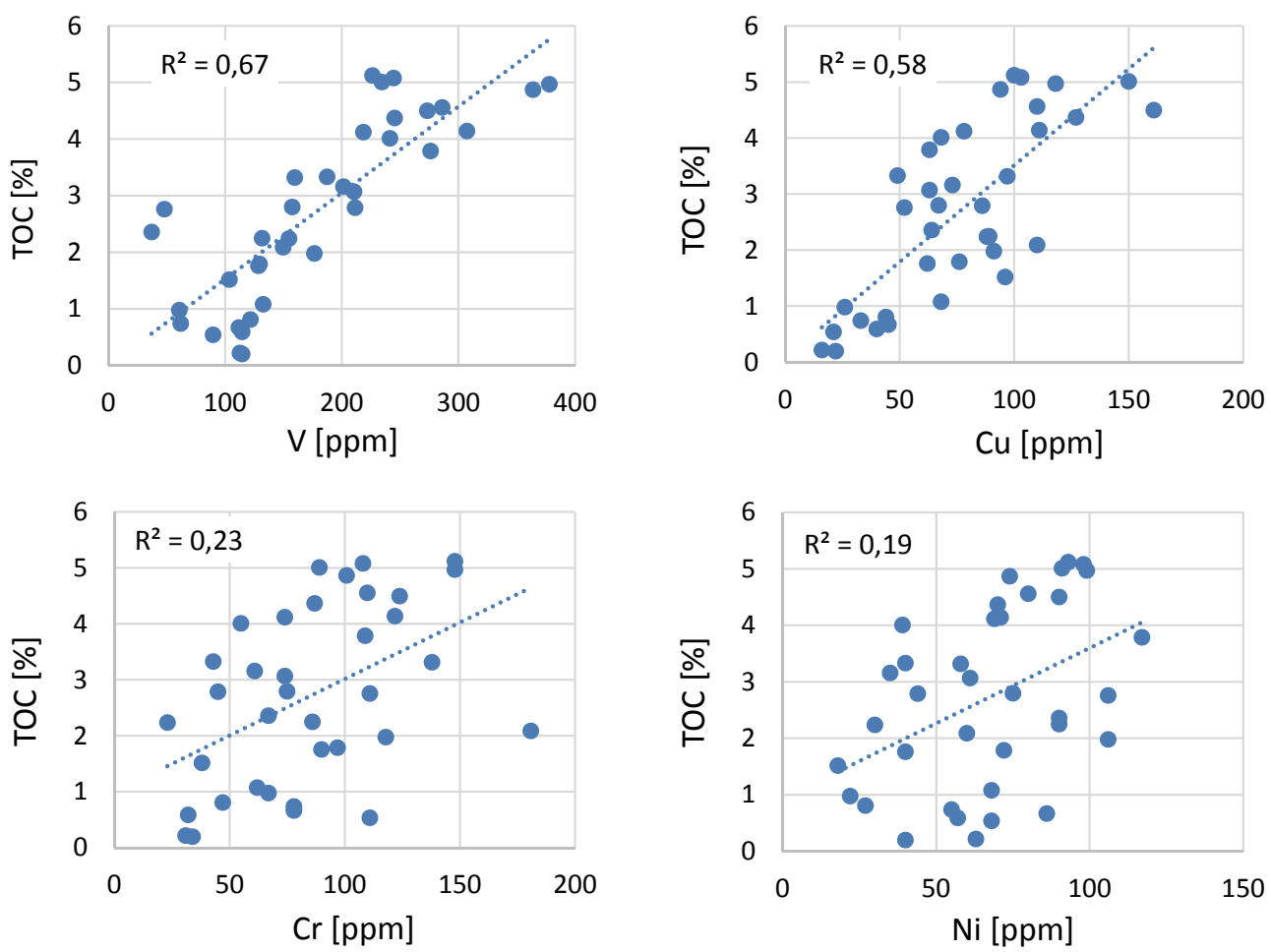

Rys. 4. Korelacje zawartości wybranych pierwiastków śladowych pomierzonych metodą XRF z zawartością materii organicznej TOC w łupkach sylurskich

Fig. 4. Correlations of selected trace elements measured by XRF with total organic content TOC in Silurian shales

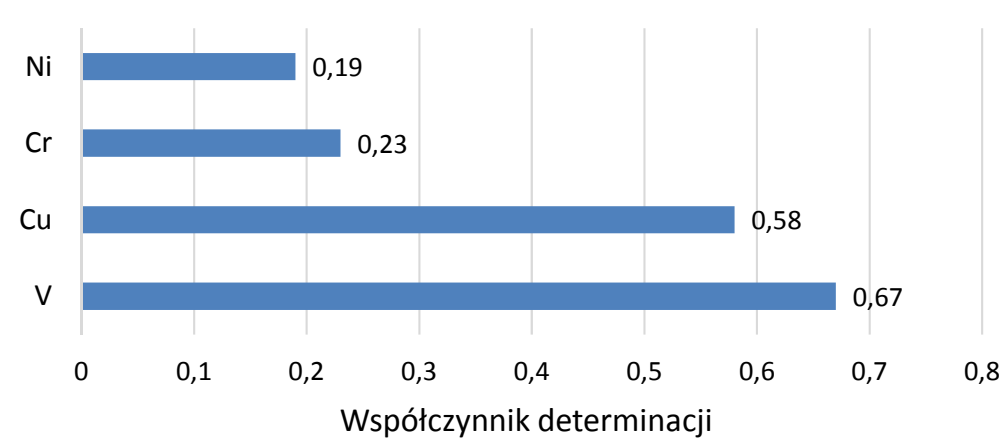

Rys. 5. Współczynniki determinacji pomiędzy wybranymi pierwiastkami śladowymi pomierzonymi metodą XRF a zawartością materii organicznej TOC w łupkach sylurskich

Fig. 5. Coefficients of determination between selected trace elements measured by XRF and total organic carbon TOC in Silurian shales

\section{Modele matematyczne umożliwiające wyliczanie wartości TOC na podstawie zawartości pierwiastków śladowych}

Regresja wieloraka to metoda statystyczna analizująca zależności pomiędzy zmienną zależną ( $w$ naszym przypadku TOC) a kilkoma zmiennymi niezależnymi (zawartość pierwiastków śladowych). Miarą jakości zbudowanego modelu są współczynnik determinacji wielorakiej $R^{2}$ i błąd standardowy estymacji $e$. Błąd estymacji $e$ wskazuje na rozbieżność pomiędzy obserwowanymi wartościami zmiennej zależnej a wartościami wyliczonymi na podstawie modelu, a zatem powinien być jak najmniejszy. Współczynnik determinacji jest miarą dopasowania modelu, miarą stopnia, w jakim model wyjaśnia kształtowanie się zmiennej zależnej. Przyjmuje wartości z przedziału $[0 ; 1]$ i powinien być jak największy. Wartość współczynnika $R^{2}$ zależy od dopasowania modelu, ale jest również wrażliwa na liczbę zmiennych w modelu i liczność próby, dlatego też w programie wyznaczana jest poprawiona wartość tego parametru. W przedstawionych poniżej modelach podawany jest poprawiony współczynnik determinacji. Program STATISTICA umożliwia również wykonanie analizy reszt (różnica pomiędzy wartością obserwowaną a przewidywaną), pozwalającej na znalezienie wartości odstających. Jeśli reszta jest oddalona więcej niż o dwa odchylenia standardowe od wartości średniej, to wartość przewidywaną można uznać za odstającą i należy ją usunąć z modelu.

Analiza regresji została przeprowadzona dla zawartości pierwiastków śladowych pomierzonych metodami ICP-MS (tabela 2, rys. 6) i XRF (tabela 3, rys. 7).

W wyniku analizy pomiarów wykonanych metodą ICP-MS otrzymano trzy modele (tabela 2) pozwalające na wyliczanie wartości TOC na podstawie zawartości pierwiastków śladowych. W modelu 1 uwzględniono wszystkie pierwiastki, dla których zaobserwowano związki korelacyjne z TOC (rys. 3) - uzyskano wysoki współczynnik determinacji $\left(\mathrm{R}^{2}=0,84\right)$ 
(tabela 2, rys. 6). Następnie skonstruowano model 2, oparty na pierwiastkach najlepiej korelujących z TOC (V, Cu, U), otrzymując nieco wyższy współczynnik determinacji $\left(\mathrm{R}^{2}=0,86\right)$ (tabela 2, rys. 6). Najlepszy wynik (model 3, $\mathrm{R}^{2}=0,92$ ) uzyskano po odrzuceniu dwóch wartości odstających z modelu 2 (określonych na podstawie analizy reszt) (tabela 2, rys. 6).

W wyniku analizy pomiarów wykonanych metodą XRF otrzymano trzy modele (tabela 3) pozwalające na wyliczanie wartości TOC na podstawie zawartości pierwiastków śladowych. W modelu 1 uwzględniono wszystkie pierwiastki, dla których zaobserwowano związki korelacyjne z TOC (rys. 5) i uzyskano współczynnik determinacji $\mathrm{R}^{2}=0,75$ (tabela 3, rys. 7). Następnie skonstruowano model oparty na pierwiastkach najlepiej korelujących z TOC (V, Cu), otrzymując ten sam współczynnik determinacji $\left(\mathrm{R}^{2}=0,75\right)$ (tabela 3 , rys. 7). Najlepszy wynik (model $3, \mathrm{R}^{2}=0,78$ ) uzyskano po odrzuceniu jednej wartości odstającej z modelu 2 (określonej na podstawie analizy reszt) (tabela 3 , rys. 7).

Tabela 2. Parametry modeli matematycznych przy zastosowaniu regresji wielorakiej dla zawartości pierwiastków śladowych pomierzonych metodą ICP-MS. Modele skonstruowano na podstawie danych uzyskanych dla 24 próbek

Table 2. Values of multiple regression parameters for mathematical models constructed with trace element contents measured by ICP-MS. Models were constructed on the basis of data obtained for 24 samples

\begin{tabular}{|c|c|c|c|c|c|c|c|c|c|}
\hline Model & $\mathbf{R}^{2}$ & e & $\mathbf{a}_{0}$ & $\mathbf{a}_{1}$ & $\mathbf{a}_{2}$ & $\mathbf{a}_{3}$ & $\mathbf{a}_{4}$ & $\mathbf{a}_{5}$ & $\mathbf{a}_{6}$ \\
\hline \multicolumn{10}{|c|}{ Model o postaci: $T O C=f(V, C u, U, N i, M o, C r)=a_{0}+a_{1} V+a_{2} C u+a_{3} U+a_{4} N i+a_{5} M o+a_{6} C r$} \\
\hline 1 & 0,84 & 0,74 & $-0,737$ & 0,007 & 0,011 & 0,051 & 0,001 & $-0,005$ & 0,003 \\
\hline \multicolumn{10}{|c|}{ Model o postaci: $T O C=f(V, C u, U)=a_{0}+a_{1} V+a_{2} C u+a_{3} U$} \\
\hline 2 & 0,86 & 0,69 & $-0,542$ & 0,007 & 0,014 & 0,047 & & & \\
\hline 3 & 0,92 & 0,53 & $-0,551$ & 0,007 & 0,017 & $-0,012$ & & & \\
\hline
\end{tabular}

Objaśnienia: model 1 - model oparty na zawartościach wszystkich analizowanych pierwiastków, dla których zaobserwowano związki z TOC, model 2 model oparty na zawartościach trzech pierwiastków najlepiej korelujących z TOC, model 3 - model oparty na zawartościach trzech pierwiastków najlepiej korelujących z TOC po odrzuceniu dwóch wartości odstających
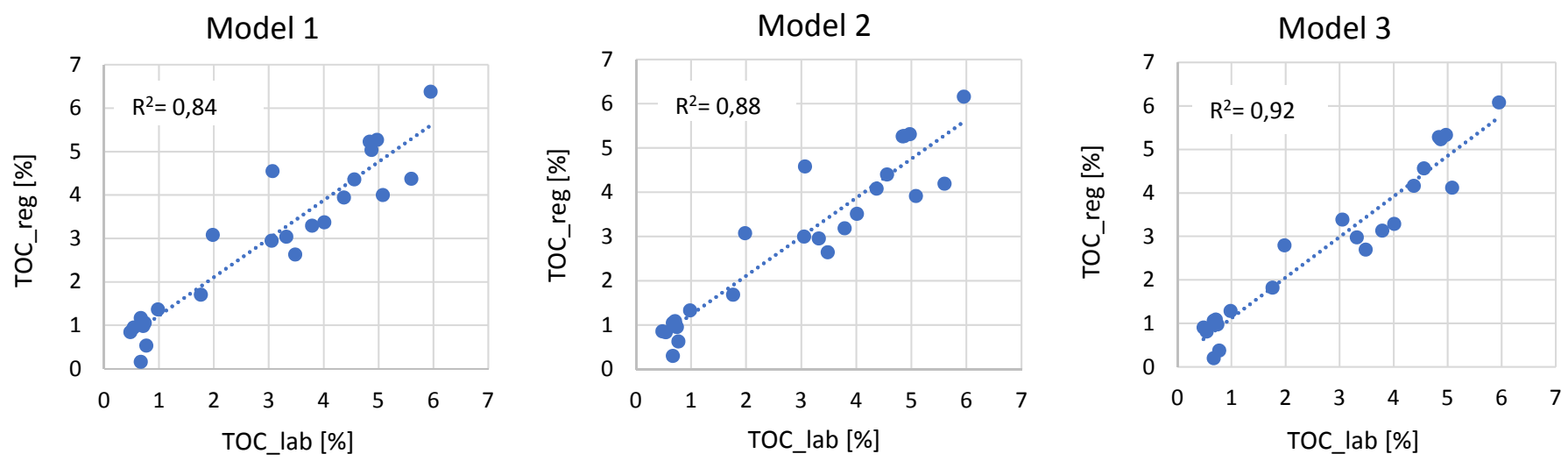

Rys. 6. Korelacja pomiędzy zawartością materii organicznej pomierzoną $\left(\mathrm{TOC}_{\mathrm{lab}}\right.$ ) i wartością estymowaną na podstawie regresji wielorakiej $\left(\mathrm{TOC}_{\text {reg }}\right.$ ) dla pomiarów pierwiastków śladowych metodą ICP-MS; model 1 - model oparty na wszystkich pierwiastkach, dla których zaobserwowano związki z TOC, model 2 - model oparty na zawartościach trzech pierwiastków najlepiej korelujących z TOC, model 3 model oparty na zawartościach trzech pierwiastków $(\mathrm{V}, \mathrm{Cu}, \mathrm{U})$ najlepiej korelujących z TOC po odrzuceniu dwóch wartości odstających

Fig. 6. Correlation between measured total organic content $\left(\mathrm{TOC}_{\mathrm{lab}}\right.$ ) and the value estimated by regression models $\left(\mathrm{TOC}_{\mathrm{reg}}\right)$ for trace element contents measured by ICP-MS; model 1 - model based on all the elements for which correlations with TOC were observed, model 2 - model based on the contents of three elements best correlated with TOC, model 3 - model based on the contents of three elements best correlated with TOC after exclusion of two outliers

\section{Wnioski}

1. Stwierdzono dobre korelacje pomiędzy zawartością wybranych pierwiastków śladowych a ilością materii organicznej TOC dla głębokomorskich łupków sylurskich. Zależności takie zaobserwowano zarówno w przypadku bardziej dokładnych pomiarów wykonanych metodą spektrometrii masowej ICP-MS, jak i badań o niższej wykrywalności przeprowadzonych za pomocą przenośnego spektrometru fluorescencji rentgenowskiej (EDXRF).

2. W przypadku badań wykonanych metodą ICP-MS najlepsze korelacje otrzymano dla V, U i Cu ( $\mathrm{R}^{2}$ powyżej 0,68). Zależności nieco słabsze, ale również świadczące o wyraźnym związku między poszczególnymi pierwiastkami a TOC 
Tabela 3. Parametry modeli matematycznych otrzymane przy zastosowaniu regresji wielorakiej dla zawartości pierwiastków śladowych pomierzonych metodą XRF. Modele skonstruowano na podstawie danych uzyskanych dla 35 próbek

Table 3. Values of multiple regression parameters for mathematical models constructed with trace element contents measured by XRF. Models were constructed on the basis of data obtained for 35 samples

\begin{tabular}{|c|c|c|c|c|c|c|c|}
\hline Model & $\mathbf{R}^{2}$ & e & $\mathbf{a}_{0}$ & $\mathbf{a}_{1}$ & $\mathbf{a}_{2}$ & $\mathbf{a}_{3}$ & $\mathbf{a}_{4}$ \\
\hline \multicolumn{8}{|c|}{ Model o postaci: $\mathrm{TOC}=\mathrm{f}(\mathrm{V}, \mathrm{Cu}, \mathrm{Cr}, \mathrm{Ni})=\mathrm{a}_{0}+\mathrm{a}_{1} \mathrm{~V}+\mathrm{a}_{2} \mathrm{Cu}+\mathrm{a}_{3} \mathrm{Cr}+\mathrm{a}_{4} \mathrm{Ni}$} \\
\hline Model 1 & 0,75 & 0,79 & $-0,892$ & 0,010 & 0,016 & 0,0003 & 0,008 \\
\hline \multicolumn{8}{|c|}{ Modele o postaci: $T O C=f(V, C u)=a_{0}+a_{1} V+a_{2} C u$} \\
\hline Model 2 & 0,75 & 0,79 & $-0,520$ & 0,010 & 0,018 & & \\
\hline Model 3 & 0,78 & 0,73 & $-0,739$ & 0,012 & 0,017 & & \\
\hline
\end{tabular}

Objaśnienia: model 1 - model oparty na zawartościach wszystkich analizowanych pierwiastków, dla których zaobserwowano związki z TOC, model 2 - model oparty na zawartościach dwóch pierwiastków (V, Cu) najlepiej korelujących z TOC, model 3 - model oparty na zawartościach dwóch pierwiastków najlepiej korelujących z TOC po odrzuceniu wartości odstającej

Model 1

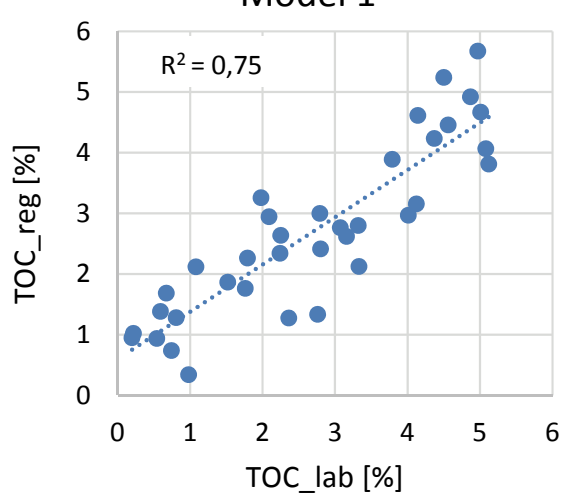

Model 2

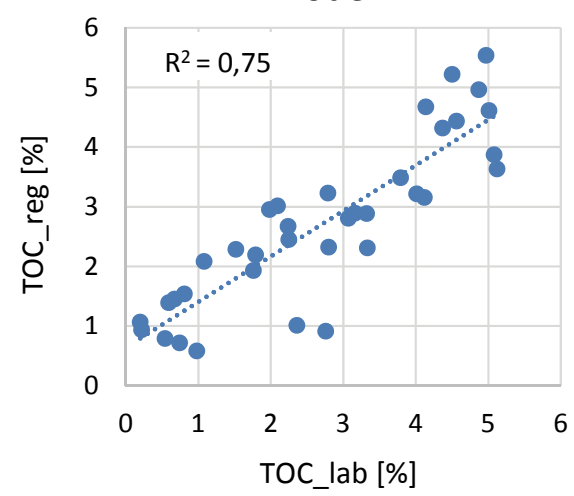

Model 3

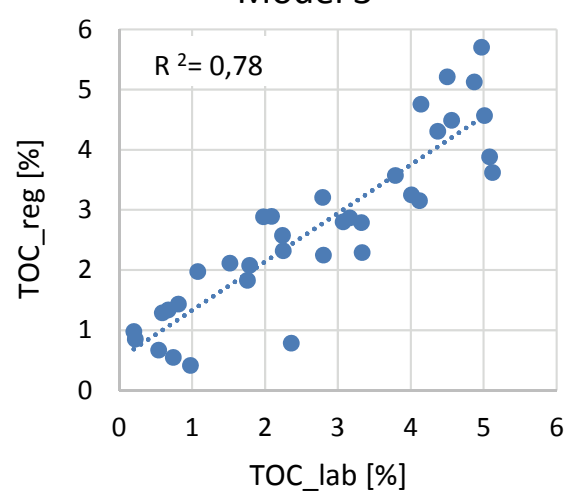

Rys. 7. Korelacja pomiędzy zawartością materii organicznej pomierzoną ( $\mathrm{TOC}_{\mathrm{lab}}$ ) i wartością estymowaną na podstawie regresji wielorakiej $\left(\mathrm{TOC}_{\text {reg }}\right)$ dla pomiarów pierwiastków śladowych metodą XRF; model 1 - model oparty na wszystkich pierwiastkach, dla których zaobserwowano związki z TOC, model 2 - model oparty na zawartościach dwóch (V, Cu) pierwiastków najlepiej korelujących z TOC, model 3 - model oparty na zawartościach dwóch pierwiastków najlepiej korelujących z TOC po odrzuceniu wartości odstającej

Fig. 7. Correlation between measured total organic content $\left(\mathrm{TOC}_{\text {lab }}\right)$ and the value estimated by regression models $\left(\mathrm{TOC}_{\text {reg }}\right)$ for trace element contents measured by XRF; model 1 - model based on all the elements for which correlations with TOC were observed, model 2 - model based on the contents of three elements best correlated with TOC, model 3 - model based on the contents of three elements best correlated with TOC after exclusion of the outlier

otrzymano dla Ni, Cr i Mo. Uzyskane związki korelacyjne umożliwiły utworzenie modeli pozwalających na wyliczenie ilości materii organicznej TOC na podstawie zawartości wybranych pierwiastków śladowych. Przy zastosowaniu regresji wielorakiej utworzono trzy modele uwzględniające zarówno wszystkie pierwiastki, dla których zaobserwowano związki korelacyjne z TOC (model $1, \mathrm{R}^{2}=0,84$ ), jak i wybrane pierwiastki $(\mathrm{V}, \mathrm{Cu}, \mathrm{U})$ najlepiej korelujące z TOC (model 2, $\mathrm{R}^{2}=0,86$ i model $3, \mathrm{R}^{2}=0,92$ ).

3. Zależności pomiędzy zawartością pierwiastków śladowych pomierzonych metodą fluorescencji rentgenowskiej (XRF) i TOC są słabsze niż w przypadku opisanej powyżej metody ICP-MS. Wyraźne korelacje $\left(\mathrm{R}^{2}>0,58\right)$ uzyskano dla $\mathrm{V}$ i $\mathrm{Cu}$, pewna zależność widoczna jest również dla Ni i Cr. Przy zastosowaniu regresji wielorakiej utworzono trzy modele pozwalające na wyliczanie wartości
TOC na podstawie zawartości pierwiastków śladowych. Najwyższym współczynnikiem determinacji $\left(\mathrm{R}^{2}=0,78\right)$ charakteryzuje się model oparty na pierwiastkach najlepiej korelujących z TOC $(\mathrm{V}, \mathrm{Cu})$.

4. Otrzymane modele matematyczne pozwalają na wyliczanie zawartości materii organicznej TOC dla głębokomorskich łupków sylurskich zarówno na podstawie pomiarów pierwiastków śladowych metodą spektrometrii masowej ICP-MS, jak i metodą fluorescencji rentgenowskiej XRF. Szczególnie istotna jest możliwość wykorzystania pomiarów wykonanych za pomocą przenośnego spektrometru fluorescencji rentgenowskiej. Badania te są szybkie i mogą być prowadzone na próbkach okruchowych w czasie trwania wiercenia. Modele oparte na wynikach XRF pozwalają więc w szybki sposób modelować zawartości TOC jeszcze $\mathrm{w}$ trakcie wiercenia. 
Artykuł powstał na podstawie pracy statutowej pt. Multidyscyplinarne podejście do badań skał bogatych $w$ materię organiczna o zróżnicowanej litologii - praca INiG - PIB na zlecenie MNiSW; nr zlecenia: 0030/SW/2020, nr archiwalny: DK-4100-0030/2020.

\section{Literatura}

Algeo T.J., Maynard J.B., 2004. Trace-element behavior and redox facies in core shales of Upper Pennsylvanian Kansas-type cyclothems. Chemical Geology, 206: 289-318. DOI:10.1016/j. chemgeo.2003.12.009.

Alnahwi A., Loucks R.G., 2019. Mineralogical composition and total organic carbon quantification using X-ray fluorescence data from the Upper Cretaceous Eagle Ford Group in southern Texas. AAPG Bulletin, 103, 2891-2907. DOI:10.1306/04151918090.

Craigie N., 2018. Principles of Elemental Chemostratigraphy. A Practical User Guide. Wyd. Springer.

Liu X., Colman S.M., Brown E.T., Minor E.C., Li H., 2013. Estimation of carbonate, total organic carbon, and biogenic silica content by FTIR and XRF techniques in lacustrine sediments. Journal of Paleolimnology, 50: 387-398. DOI: 10.1007/s10933-013-9733-7.

Marsala A.F., Loermans T., Shen S., Scheibe C., Zereik R., 2011. Realtime mineralogy, lithology and chemostratigraphy while drilling using energy-dispersive x-ray fluorescence. SPE EUROPEC/ EAGE Annual Conference and Exhibition, Vienna, Austria, May 23-26, 2011. SPE-143468-MS. DOI: 10.2118/143468-MS.

Matyasik I. (red.), 2017. Polskie Technologie dla Gazu Łupkowego Blue Gas. Metodologia wyznaczania sweet spotów na podstawie własności geochemicznych, petrofizycznych, geomechanicznych w oparciu o korelację wyników badań laboratoryjnych z pomiarami geofizycznymi i model generacyjny 3D. Archiwum Instytutu Nafty i Gazu - Państwowego Instytutu Badawczego, Kraków.

Matyasik I., Janiga M., Spunda K., 2020. Ewaluacja sweet spotów w polskich formacjach łupkowych w odniesieniu do wybranych parametrów geochemicznych. Nafta-Gaz, 2: 76-90. DOI: 10.18668/NG.2020.02.02.

Matyasik I., Kierat M., Brzuszek P., Bieleń W., 2016. Ocena zdolności skał paleozoicznych do generowania określonego typu węglowodorów na podstawie wyników badań geochemicznych uzyskanych w ramach realizacji projektu Blue Gas. Prace Naukowe Instytutu Nafty i Gazu - Państwowego Instytutu Badawczego, wyd. konferencyjne, 209: 443-447.

Morse J.W., Luther III G.W., 1999. Chemical influences on trace metal-sulfide interactions in anoxic sediments. Geochim. Cosmochim. Acta, 63: 3373-3378. DOI: 10.1016/S0016-7037(99)00258-6.

Pailler D., Bard E., Rostek F., Zheng Y., Mortlock R., van Geen A., 2002. Burial of redox-sensitive metals and organic matter in the equatorial Indian Ocean linked to precession. Geochim. Cosmochim. Acta, 66: 849-865. DOI:10.1016/S0016-7037(01)00817-1.

Saez A., Valero-Garcés B.L., Giralt S., Moreno A., Bao R., Pueyo J.J., Hernández A., Casas D., 2009. Glacial to Holocene climate changes in Easter Island (SE Pacific, $\left.27^{\circ} \mathrm{S}\right)$. Quaternary Science Reviews, 28: 2743-2759. DOI: 10.1016/j.quascirev.2009.06.018.

Skupio R., 2014. Wykorzystanie przenośnego spektrometru XRF do pomiarów składu chemicznego skał. Nafta-Gaz, 11: 771-777.

Skupio R., Zagórska U., Kowalska S., 2020. Kalibracja wyników analiz chemicznych piaskowców czerwonego spągowca wykonanych przenośnym spektrometrem XRF. Nafta-Gaz, 1: 12-17. DOI: 18668/NG.2020.01.02.

Tribovillard N., Algeo T.J., Lyons T., Riboulleau A., 2006. Trace metals as paleoredox and paleoproductivity proxies: An update. Chemical Geology, 232: 12-32. DOI:10.1016/j.chemgeo.2006.02.012.

Tyson R.V., Pearson T.H., 1991. Modern and ancient continental shelf anoxia: an overview. [W:] Tyson R.V., Pearson T.H. (eds.). Modern and ancient continental shelf anoxia. Geol. Soc. Spec. Publ., 58: 1-26. DOI: 10.1144/GSL.SP.1991.058.01.01.

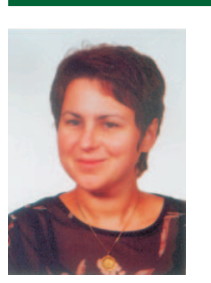

Mgr Anna PRZELASKOWSKA

Starszy specjalista badawczo-techniczny w Zakładzie Geofizyki Wiertniczej

Instytut Nafty i Gazu - Państwowy Instytut Badawczy ul. Lubicz 25 A

31-503 Kraków

E-mail: anna.przelaskowska@inig.pl

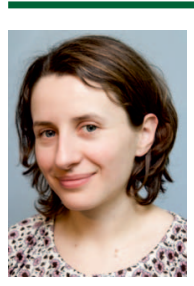

Mgr Urszula ZAGÓRSKA

Asystent w Zakładzie Geofizyki Wiertniczej

Instytut Nafty i Gazu - Państwowy Instytut Badawczy ul. Lubicz 25 A

31-503 Kraków

E-mail: urszula.zagorska@inig.pl

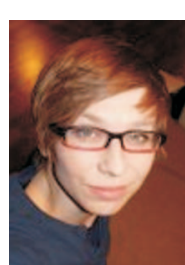

Dr inż. Maja MROCZKOWSKA-SZERSZEN

Adiunkt w Zakładzie Geologii i Geochemii

Instytut Nafty i Gazu - Państwowy Instytut Badawczy ul. Lubicz 25 A

31-503 Kraków

E-mail: mroczkowska@inig.pl

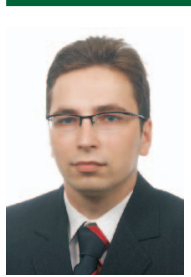

Dr Konrad ZIEMIANIN

Adiunkt w Zakładzie Geologii i Geochemii Instytut Nafty i Gazu - Państwowy Instytut Badawczy ul. Lubicz 25 A

31-503 Kraków

E-mail: konrad.ziemianin@inig.pl 